(c) American Dairy Science Association, 2005.

\title{
Aminopeptidase N Gene Expression and Abundance in Caprine Mammary Gland is Influenced by Circulating Plasma Peptide
}

\author{
S. J. Mabjeesh, ${ }^{1}$ O. Gal-Garber, ${ }^{1}$ J. Milgram, ${ }^{2}$ Y. Feuermann, ${ }^{1}$ M. Cohen-Zinder, ${ }^{1}$ and A. Shamay ${ }^{3}$ \\ ${ }^{1}$ Department of Animal Sciences, Faculty of Agricultural, Food and Environmental Quality Sciences, and \\ ${ }^{2}$ The Koret School of Veterinary Medicine, The Hebrew University of Jerusalem, PO Box 12, Rehovot, Israel \\ ${ }^{3}$ Agricultural Research Organization, Volcani Center, Institute of Animal Science, Bet Dagan, Israel
}

\section{ABSTRACT}

This study examined the localization and the effect of circulating peptides on the expression of aminopeptidase N (EC 3.4.11.2) in caprine mammary gland. Four lactating goats in mid to late lactation were used in a crossover design and were subjected to 2 dietary treatments. Abomasal infusion of casein hydrolysate was used to increase the concentration of peptide-bound amino acid in the circulation. Samples of mammary gland tissue from each goat were taken by biopsy at the end of each treatment period to measure gene and protein expression of aminopeptidase $\mathrm{N}$ in the tissue. There were no measurable effects on feed intake and milk production for any of the treatments. Western blot analysis showed that aminopeptidase $\mathrm{N}$ is located on the basolateral side of parenchymal cells and not on the apical membranes. Abomasal infusion of casein hydrolysate caused a marked change in the profile of arterial blood free amino acids and peptide-bound amino acids smaller than $1500 \mathrm{Da}$. Abundance of aminopeptidase $\mathrm{N}$ mRNA and protein increased by 51 and $58 \%$, respectively, in casein hydrolysate-infused goats compared with the control treatment. It was concluded that aminopeptidase $\mathrm{N}$ is one candidate actively involved in the mammary gland to support protein synthesis and milk production. In accordance with the nutritional conditions in the current experiment, it is suggested that aminopeptidase $\mathrm{N}$ expression is partly controlled by the metabolic requirements of the gland and postabsorptive forms of amino acids in the circulation.

(Key words: mammary gland, aminopeptidase N, peptide)

Abbreviation key: AP = alkaline phosphatase, $\mathbf{A P N}=$ aminopeptidase N, CAS20 and CAS40 = casein hydrolysate infusions providing an additional 20 and $40 \%$ MP, respectively, CAS30 = casein hydrolysate infusion

Received December 7, 2004.

Accepted March 10, 2005.

Corresponding author: S. J. Mabjeesh; e-mail: Mabjeesh@agri. huji.ac.il. replacing $30 \%$ of MPI, FAA $=$ free amino acid, $\gamma-\mathbf{G T}=\gamma-$ glutamyl transpeptidase, $\mathbf{M P}=$ metabolizable protein, MPI = metabolizable protein intake, PBAA = peptidebound AA, PMV = plasma membrane vesicles.

\section{INTRODUCTION}

Milk from ruminants provides more than $30 \%$ of animal protein in the human diet worldwide (Taylor and Field, 1998). Researchers and producers are constantly searching for methods to further increase yield per animal to improve production efficiency. For example, only $35 \%$ (on an additive basis) of AA was converted to milk protein when cows were supplied with AA to compensate for $\mathrm{N}$ deficiency caused by dietary management (Bequette et al., 1998). The apparent low efficiency of converting AA to milk protein in the udder could be related to the fact that the balance measurements across the mammary gland are done on the basis of net uptake of free AA from plasma without considering the contribution of circulating peptide-bound AA (PBAA). Although, the actual contributions of PBAA to net protein metabolism in the udder are small, it is important to consider their metabolic impact (Bequette et al., 1998).

Transport of PBAA is an important physiological process that occurs in tissues of animals (Matthews, 1991). Peptide-bound AA may constitute a portion of total AA absorption in ruminants (McCormick and Webb, 1982; Danilson et al., 1987) and peptide transporters are present in tissues of sheep, cows, pigs, and chickens (Matthews et al., 1996a,b; Pan et al., 1997, 2001; Chen et al., 1999). Northern blot analysis conducted with tissues from sheep and lactating Holstein cows showed the presence of a 2.8 -kb mRNA transcript for the peptide transporter, PepT1, in the omasum, rumen, duodenum, jejunum, and ileum (Chen et al., 1999). No hybridization was observed with mRNA from the abomasum, cecum, colon, liver, kidney, and semitendinosus and longissimus muscles of either species or from the mammary tissue from the cows.

Individual tissues including the mammary gland of ruminants may be able to use AA residues of PBAA for 
protein synthesis. Cultured bovine mammary epithelial cells and tissue explants from lactating CD-1 mice used methionine from methionine-containing dipeptides to support protein accretion and synthesis of secreted proteins (Pan et al., 1996; Wang et al., 1996). Results from an in vivo experiment with lactating dairy goats indicate that mammary glands use PBAA from the circulation for protein synthesis and secretion (Backwell et al., 1996). Similar results were reported for dairy cows receiving different dietary treatments (Tagari et al., 2004). However, in the absence of peptide transporter in the mammary gland, the mechanism(s) of action may be external PBAA hydrolysis and absorption of the liberated $\mathrm{AA}$ in the free form.

Recently, it was shown that rodent mammary tissue expresses a variety of dipeptidases on the basolateral surface of the epithelial cells that are capable of hydrolyzing peptides extracellularly (Shennan et al., 1998, 1999). Previously, we showed that aminopeptidase N (APN; EC 3.4.11.2) is expressed in the mammary gland of goats and cows (Mabjeesh et al., 2001). Aminopeptidase $\mathrm{N}$ enzyme plays an important role in protein digestion and absorption in the small intestine; its activity in the plasma membrane of the mammary epithelium may explain how PBAA from the circulation are internalized by the mammary gland (Mabjeesh et al., 2001).

The purpose of the current study was to investigate the location of APN in the mammary gland and whether the concentration of circulating peptides affects and controls the expression of APN in the mammary gland in vivo. For this experiment, goats in mid to late lactation were used. The abomasal infusion of casein hydrolysate was used to increase the concentration of PBAA in the circulation. Some of the results of this experiment have been published in preliminary form (Mabjeesh et al., 2001).

\section{MATERIALS AND METHODS}

\section{Animals, Feeding, and Treatments}

All surgical and experimental procedures were approved by the Animal Care and Ethics Committee of the Hebrew University of Jerusalem. Two experiments were conducted. The first was preliminary and was conducted on 2 multiparous Israeli Saanen dairy goats in late lactation (180 $\pm 30 \mathrm{DIM}$ and $879 \pm 97 \mathrm{~g} / \mathrm{d}$ of milk). Goats were surgically prepared with abomasal cannulas to allow infusion and a raised carotid artery to allow arterial blood sampling. Goat handling, management, and the abomasal infusion protocol were similar to the second experiment (see details below). Goats were assigned to 3 experimental periods that each lasted $14 \mathrm{~d}$. Abomasal infusates were water or water plus casein at
2 levels of metabolizable protein intake (MPI; 20 and $40 \%$; basal MPI $=116.3 \pm 7.2 \mathrm{~g} / \mathrm{d}$ ) above that available to the goats from the diet, e.g., infusate increased the actual supply of metabolizable protein (MP) by 20 and $40 \%$ of the daily intake of MP. The order of treatments that each goat received was control, casein hydrolysate with $20 \%$ increased MP (CAS20), and casein hydrolysate with 40\% increased MP (CAS40). Milk production and feed intake were monitored over the last $7 \mathrm{~d}$ of each period.

The second experiment was conducted on primiparous Israeli Saanen goats $(\mathrm{n}=4$; $\mathrm{BW}=55 \pm 6 \mathrm{~kg})$ in mid to late lactation (160 \pm 25 DIM). Goats were used in a crossover design. In period 1 , goats were randomly assigned ( 2 per treatment) to 2 dietary treatments, and one udder half was randomly selected for monitoring and sampling. During period 2, dietary treatments were switched and the contralateral udder half was monitored and sampled. Goats were surgically prepared with abomasal cannulas. Two goats were prepared by raised carotid arrangement as described above.

Goats were placed in metabolism crates and allowed at least $10 \mathrm{~d}$ of adaptation to frequent feeding of diets by automatic feeders (12 equal portions daily at $2-\mathrm{h}$ intervals) and the daily routines of machine and handmilking (0700 and $1900 \mathrm{~h}$ ). Milk weights were recorded at each milking. The diet was formulated to meet metabolizable energy and protein requirements for maintenance and milk production (AFRC, 1992, 1993) and contained $40 \%$ chopped vetch-clover hay, $60 \%$ concentrate feeds, and relevant vitamin and mineral mixes (Table 1). The concentrates contained commercial pellets (1474, Matmor Ltd., Ashdod, Israel), barley, and corn whole grains. Daily feed refusals were collected and weighed, and feed intake was adjusted to allow $10 \%$ refusals.

Treatments in the preliminary study were: 1 ) control, abomasal infusion of water $(1000 \mathrm{~g} / \mathrm{d}), 2)$ abomasal infusion of casein hydrolysate (Sigma no. A-2427; SigmaAldrich, Ltd., Rehovot, Israel) CAS20, and 3) abomasal infusion of casein hydrolysate CAS40 dissolved (emulsified) in $1000 \mathrm{~g} / \mathrm{d}$ of $\mathrm{H}_{2} \mathrm{O}$. Infusion was conducted by peristaltic pump (Minipuls 2, Gilson, Paris, France). The quantity of casein hydrolysate infused was fixed to deliver an added 20 or $40 \%$ of the MPI and was adjusted daily based on feed intake. Small intestine digestibility of casein was assumed $100 \%$ in accordance with our previous in vivo findings with sheep (Mabjeesh et al., 2003), thus all CP of casein $(81.7 \mathrm{~g} / 100 \mathrm{~g}$ of raw material) was considered MP.

Treatments in the main study were: 1) control-abomasal infusion of $\left.\mathrm{H}_{2} \mathrm{O}(1000 \mathrm{~g} / \mathrm{d}), 2\right)$ abomasal infusion of casein hydrolysate (Sigma no. A-2427; Sigma-Aldrich) dissolved (emulsified) in $1000 \mathrm{~g} / \mathrm{d}$ of $\mathrm{H}_{2} \mathrm{O}$. Infusion 
Table 1. Composition of diet and chemical analysis given to goats.

\begin{tabular}{lcc}
\hline Ingredient & $\begin{array}{c}\text { \% of } \\
\text { DM }\end{array}$ & $\begin{array}{c}\% \text { DM } \\
\text { of diet }\end{array}$ \\
\hline Grain pellets 1474 & & 30 \\
Soybean meal & 15.3 & \\
Rapeseed meal & 10.0 & \\
High fat product & 4.52 & \\
NPN (mixture) & \\
Poultry oil & 0.43 & \\
Barley grains & 0.5 & \\
Corn grain & 12.41 & \\
Wheat grain & 10.0 & \\
Sunflower meal & 20.0 & \\
Gluten feed & 6.10 & \\
Soybean hulls & 10.0 & \\
Salt/calcium & 8.0 & \\
Sodium sulfate & 2.14 & 15 \\
Vitamin E, 50\% & 0.007 & 15 \\
Vitamins and minerals ${ }^{3}$ & 0.014 & \\
Whole barley grain & 0.076 & \\
Whole corn grain & & 18.2 \\
Chopped vetch-clover hay & & 14.5 \\
Chemical analysis of diet & & 5.18 \\
CP & & 2.61 \\
Metabolic protein & & \\
OM & & \\
RUP & & \\
Metabolic energy, Mcal/ kg & & \\
\hline
\end{tabular}

${ }^{1}$ Grain mixture 1474 (Matmor Ltd., Ashdod, Israel).

${ }^{2}$ Contained $80 \%$ urea and $20 \%$ ammonium sulfate.

${ }^{3}$ Contained 20,000,000 IU of vitamin A/kg, 2,000,000 IU of vitamin $\mathrm{D} / \mathrm{kg}, 15,000 \mathrm{mg}$ vitamin $\mathrm{E} / \mathrm{kg}, 6000 \mathrm{mg} / \mathrm{kg}$ of Mn, $6000 \mathrm{mg} / \mathrm{kg}$ of Zn, $2000 \mathrm{mg} / \mathrm{kg}$ of Fe, $1500 \mathrm{mg} / \mathrm{kg}$ of Cu, $120 \mathrm{mg} / \mathrm{kg}$ of I, $50 \mathrm{mg} / \mathrm{kg}$ of Se, and $20 \mathrm{mg} / \mathrm{kg}$ of $\mathrm{Co}$.

was conducted by peristaltic pump (Gilson). The quantity of casein hydrolysate infused (CAS30) was fixed to replace (not extra, as in the pilot study) $30 \%$ of the MPI and was corrected daily according to refusals. To calculate the daily MPI and the casein infusate, a spreadsheet was created with the diet ingredients (pellets, corn and barely grains and hay) and their corresponding chemical composition of CP, RUP, RDP, and rumen-degradable OM. These parameters were measured in situ, and MP was calculated in accordance to AFRC model (1992) and the model suggested previously (Arieli et al., 1989). The pellets were considered the major supplement of MP and, according to daily corrected feed intake, the amount was changed in order not to exceed the total calculated MPI. To prevent severe alterations in microbial CP flow, rumen-degradable OM was calculated for the diet and kept at the semioptimal concentration by manipulating the amount of barley and corn grain in the diet. A ratio of 5:1 of rumendegradable OM:RDP was considered ideal for keeping optimal microbial CP synthesis in the rumen (Arieli et al., 1989).

\section{Sample Collection and Analysis}

In the preliminary study, on the last day of each experimental period, goats were machine milked at $0700 \mathrm{~h}$. Then, polyvinyl catheters were implanted into the carotid artery to allow blood withdrawal. Four blood samples $(10 \mathrm{~mL})$ were withdrawn from the artery every hour $(\mathrm{n}=4)$. Plasma was immediately separated by centrifugation at $3000 \times g$ for $15 \mathrm{~min}$ at $4^{\circ} \mathrm{C}$ and was stored at $-20^{\circ} \mathrm{C}$ for further analysis.

On the last day of each experimental period in the main study, goats were machine milked at $0700 \mathrm{~h}$, and mammary tissue samples ( 1.5 to $2.0 \mathrm{~g}$ ) were taken by biopsy. Four arterial blood samples were taken from 2 goats, as described earlier, before the biopsy was performed. For the biopsy procedure, goats were sedated with xylazine (Rompum, Teva Medical, Ltd., Ashdod, Israel) and local anesthesia (lidocaine, 2\%; Teva Medical) was introduced to the area (at the midupper part of the udder) of the udder half that was being monitored. Tissue samples were immediately divided into 2 portions, one of which was kept in RNAlater storage/stabilization solution (Ambion, Inc., Austin, TX) at $4^{\circ} \mathrm{C}$ and the other one was frozen with liquid $\mathrm{N}$ and stored at $-80^{\circ} \mathrm{C}$ until analysis.

\section{Plasma AA and PBAA Analysis}

Arterial plasma was prepared for free amino acid (FAA) and PBAA analysis by the method of Backwell et al. (1997). Plasma proteins were precipitated by combining plasma with $1 M$ perchloric acid (1:1 vol/vol) that contained norleucine $(25.6 \mathrm{mg} / \mathrm{L})$ as an external standard. The combination was mixed thoroughly. Samples were centrifuged at $1500 \times g$ at $4^{\circ} \mathrm{C}$ for $15 \mathrm{~min}$, and the supernatant was re-centrifuged under the same conditions to remove any residual protein. The supernatant was then neutralized ( $\mathrm{pH} 7$ to 8 ) by adding $2 M$ $\mathrm{K}_{2} \mathrm{CO}_{3}$ and allowed to stand for $2 \mathrm{~h}$ at $4^{\circ} \mathrm{C}$ before the precipitated perchlorate salt was removed by centrifugation as described above. The supernatant was applied to a Sephadex G-15 column (volume $5 \mathrm{~mL}$; Pharmacia Biotech AB, Uppsala, Sweden) equilibrated in $0.2 \mathrm{M}$ ammonium bicarbonate, $\mathrm{pH}$ 8.0, and eluted with the same buffer at a flow rate of $0.3 \mathrm{~mL} / \mathrm{min}$ on an ÄKTAprime fast performance liquid chromatography system (Amersham Pharmacia Biotech $\mathrm{AB}$ ). The column void volume (2 column volumes, approximately $10 \mathrm{~mL}$ ), which contained residual soluble protein or peptides of molecular weight $>1500 \mathrm{Da}$, was discarded and, thereafter, fractions that contained peptides of $\mathrm{MW}<1500$ Da were collected, pooled, and lyophilized. Dried samples were stored until analyzed for FAA and PBAA by HPLC using the Pico-Tag method (Waters Corp., Milford, MA) (Bidlingmeyer et al., 1984). The PBAA 
content of samples was calculated as the difference between the corrected AA content of hydrolyzed samples and the FAA content of the same sample before hydrolysis.

\section{RNA Preparation}

Total RNA was isolated from the mammary gland tissues kept in RNAlater using TRI reagent $(1 \mathrm{~mL} / 100$ $\mathrm{mg}$ of tissue) according to the manufacturer's protocol (MRC Molecular Research Center, Inc., Cincinnati, $\mathrm{OH})$.

\section{Reverse Transcription-Polymerase Chain Reaction}

The following primers were used (based on conserved regions of the published genes): forward: 5 '-CTGGGG ACTGGTGACCTACCGGG-3'; reverse: 5'-CGCTGGAC CCTCGAGATGGGCTT-3' in the reverse transcriptionPCR reaction. Total RNA was amplified using PCR Sprint equipment (Hybaid, Ltd., London, UK) utilizing the Promega Access RT-PCR system according to the manufacturer's protocol (Promega Corporation, Madison, WI). One microgram of total RNA was added to $1 \times$ AMV/Tfl $5 \times$ reaction buffer, $0.2 \mathrm{~m} M$ dNTP mix $(10 \mathrm{~m} M$ each dNTP), $1 \mu M$ upstream and downstream primers, $1 \mathrm{~m} M \mathrm{MgSO}_{4}, 0.1 \mathrm{U} / \mu \mathrm{L}$ AMV reverse transcription (5 $\mathrm{U} / \mu \mathrm{L}), 0.01 \mathrm{U} / \mu \mathrm{L}$ Tfl DNA polymerase $(5 \mathrm{U} / \mu \mathrm{L})$, and diethyl pyrocarbonate-treated water in a total volume of $50 \mu \mathrm{L}$. The reaction tubes were incubated for 1 cycle at $48^{\circ} \mathrm{C}$ for $45 \mathrm{~min}$ (for reverse transcription), 1 cycle at $94^{\circ} \mathrm{C}$ for 2 min (AMV RT inactivation and RNA/ $\mathrm{cDNA}$ /primer denaturation), 35 cycles at $94^{\circ} \mathrm{C}$ for $30 \mathrm{~s}$ (denaturation), $60^{\circ} \mathrm{C}$ for $1 \mathrm{~min}$ (annealing), $68^{\circ} \mathrm{C}$ for 2 min (extension), and 1 cycle at $68^{\circ} \mathrm{C}$ for $7 \mathrm{~min}$ (final extension).

The reverse transcription-PCR products were examined on a $1.5 \%$ agarose gel, visualized by staining with ethidium bromide, excised from the gel, and purified with a gel extraction column (Wizard PCR Preps DNA purification system, Promega). The mammary gland aminopeptidase cDNA fragment was subjected to automated sequencing using an Applied Biosystem 373A DNA sequencer (Applied Biosystems). Nucleic acid sequences were analyzed using the GCG Wisconsin suite of programs (GCG, San Diego, CA) (Devereux et al., 1984). The homology between goat and other aminopeptidase sequences was calculated using DNAMan version 4 (Lynnon Biosoft 1994-1997, Lynnon Bioinformatic Solution, Quebec, Canada).

\section{Northern Blot}

For Northern blot analysis, $30 \mu \mathrm{g}$ of total RNA was denatured and separated by electrophoresis on $1.5 \%$ agarose/1.1 $M$ formaldehyde gel. After electrophoresis, RNA was transferred overnight by capillary transfer to a nylon filter (Hybond-N; Amersham Pharmacia Biotech) and then fixed on the filter by UV at $340 \mathrm{~nm}$ for $2 \mathrm{~min}$.

\section{Hybridization}

Two probes were used for hybridization: 1) The isolated cDNA fragment of goat mammary gland aminopeptidase, and 18S cDNA (Ambion, Inc.) to normalize variations in the total RNA loading. The probes were labeled with ${ }^{32} \mathrm{P}$-dCTP by the random prime labeling method (Biological Industries, Kibbutz Beit Haemek, Israel). Prehybridization was done at $42^{\circ} \mathrm{C}$ for $4 \mathrm{~h}$, hybridization was at $42^{\circ} \mathrm{C}$ overnight, and a high-stringency wash $(0.1 \times$ saline sodium citrate/ $0.1 \%$ SDS at $60^{\circ} \mathrm{C}$ ) was conducted according to the procedures recommended by Amersham for Hybond N membranes (Amersham Pharmacia Biotech). Blots were exposed for 24 $\mathrm{h}$ at $-70^{\circ} \mathrm{C}$ to Kodak XAR 5 film in the presence of an intensifying screen.

\section{Preparation of Plasma Membrane Vesicles}

Plasma membrane vesicles (PMV) from the basal side of the parenchymal cells taken from frozen caprine mammary tissue were prepared using $\mathrm{MgCl}_{2}$ precipitation and sequential centrifugation as descried by Vayro et al. (1991). Activity of membrane markers such as alkaline phosphatase (AP; EC 3.1.41) and $\gamma$-glutamyl transpeptidase ( $\gamma$-GT; EC 2.3.2.2) in the PMV and homogenates were measured to validate the quality of the preparation. The enzymatic activity of AP and $\gamma$-GT were measured according to Sigma Diagnostics' kits (cat. no. 221 and 419, respectively, Sigma-Aldrich, Inc.). p-Nitrophenyl phosphate and L-Leu p-nitroanilide were used as substrates in the reaction to measure the activity of AP and $\gamma$-GT. The accumulation over time of $\mathrm{p}$ nitrophenyl and p-nitroanilide in the reaction medium was measured spectrophotometrically at 410 and 405 $\mathrm{nm}$, respectively. The reactions were performed at $37^{\circ} \mathrm{C}$ in cuvette cells in the spectrophotometer (UVIKON 810, Kontrom Analytical, Bunnik, Switzerland) over $7 \mathrm{~min}$ and the absorbance was recorded each $1 \mathrm{~min}$. The enrichment activity of AP and $\gamma$-GT was 11.57 and 8.85 times the original homogenate, respectively. Membranes from the apical side were prepared from bovine milk as described previously (Shennan, 1992). Bovine milk was used to isolated apical membrane because fat globules contain only membranes from the epithelial tissue (secretory cells). Fat globules from caprine milk contain a larger portion (up to intact cells) of secretory cell membrane, which makes it difficult to isolate pure 
apical membrane (Shennan, 1992). The final protein concentration in PMV was 9 to $15 \mathrm{~g} / \mathrm{L}$. Aliquots of 50 to $100 \mu \mathrm{L}$ of PMV were frozen in liquid nitrogen and stored at $-80^{\circ} \mathrm{C}$ until use.

\section{Western Blot Analysis}

The PMV were solubilized in a loading buffer consisting of $1 \%$ Triton X-100, $50 \mathrm{mM}$ HEPES, $20 \%$ glycerol, and $5 \% \quad \beta$-mercaptoethanol, and then heated at $100^{\circ} \mathrm{C}$ for $2 \mathrm{~min}$.

Samples (15 $\mu \mathrm{g}$ of protein) were separated by SDSPAGE on 10\% gels under reducing conditions (Laemmli, 1970). Following electrophoresis, proteins were transferred to nitrocellulose membranes (Schleicher and Schuell, Dassel, Germany). After blocking with TBSTween [50 mM Tris-HCl, pH 7.5, $150 \mathrm{mM} \mathrm{NaCl}$, and $0.5 \%$ (vol/vol) Tween 20] containing 3\% BSA, membranes were incubated overnight at $4^{\circ} \mathrm{C}$ with antigoat polyclonal CD 13 (APN) antibody (1:100; Santa Cruz Biotechnology, Inc., Santa Cruz, CA). Membranes were then washed with TBS-Tween and visualized using enhanced chemiluminescence by incubating for $1 \mathrm{~h}$ with horseradish peroxidase-conjugated donkey secondary antigoat IgG (1:15,000; Jackson Immuno Research Laboratories, Inc., West Grove, $\mathrm{PA}$ ) at $22^{\circ} \mathrm{C}$. A mouse monoclonal antiAPN (CD 13) $\mathrm{IgG}_{2 \mathrm{a}}$ raised against LPStreated human U937 cells (1:100; Calbiochem Biochemical and Immunochemical, Darmstadt, Germany) was also used as above for APN detection in the PMV.

\section{Statistical Analyses}

Concentrations of AA were measured on each plasma sample. The average ( $\mathrm{n}=4$ for each goat) was calculated and used in the statistical model as follows. Data, including gene and protein expression (each was performed in triplicate), were analyzed using ANOVA to compare treatment effects by the GLM procedure of SAS (SAS Institute, 1985) in a crossover design. The linear model included the effect of treatment, period, goat (random effect), and the residual error term. Means were separated using Students' $t$-test and differences were considered significant when $P<0.05$ unless stated otherwise. Data are presented as least square means \pm SEM.

\section{RESULTS}

\section{Preliminary Experiment}

Results of the preliminary experiment are presented in Figures 1 and 2. All variables measured were increased in a dose-response manner (based on regression analysis which revealed $\mathrm{R}^{2}=0.94$ to $0.99 ; P<0.021$ to
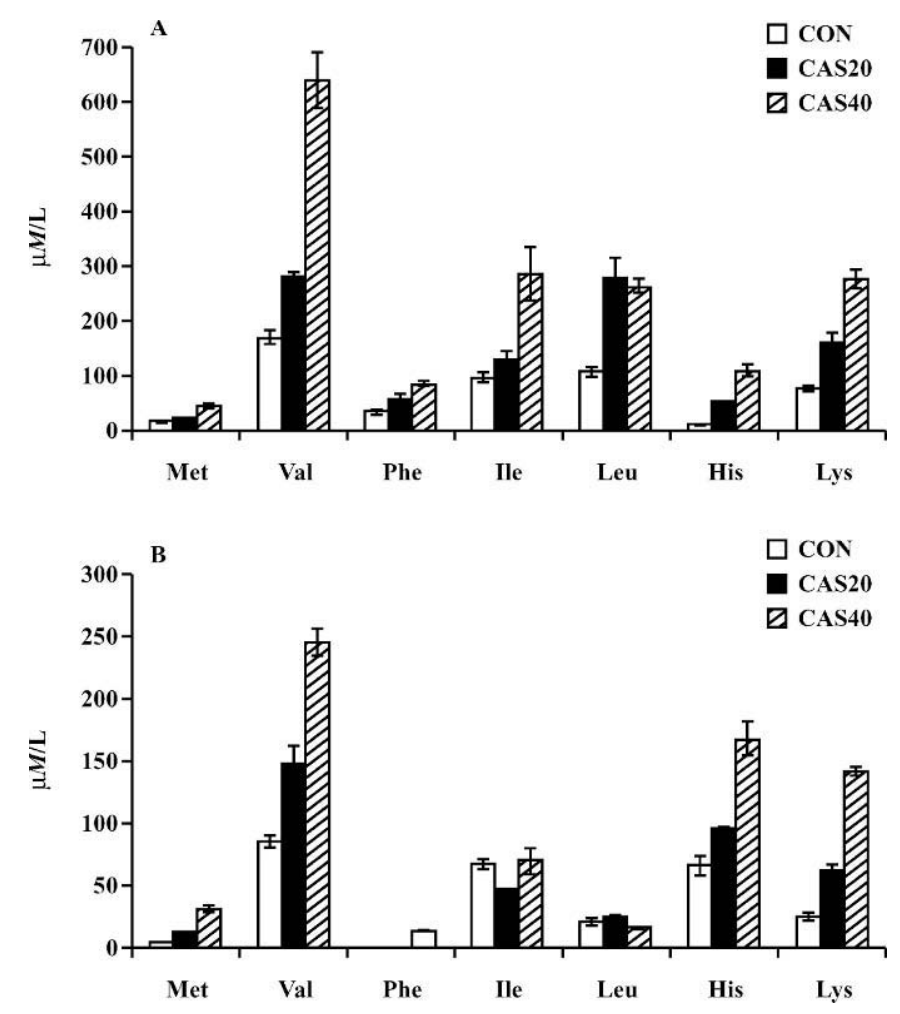

Figure 1. Concentration of free AA (A) and peptide-bound AA (B) in arterial plasma of dairy goats $(n=2)$ abomasally infused daily with $1000 \mathrm{~g}$ of water $(\mathrm{CON})$, casein hydrolysate solution equaling $20 \%$ of metabolizable protein intake (CAS20), or casein hydrolysate solution equaling $40 \%$ of metabolizable protein intake (CAS40). Results are least square means $\pm \mathrm{SE}$.

0.001) with the increased casein hydrolysate infusion. Feed intake was increased $(P<0.01)$ from $794 \mathrm{~g} / \mathrm{d}$ up to 1334 and $1814 \mathrm{~g} / \mathrm{d}$ when goats were infused with

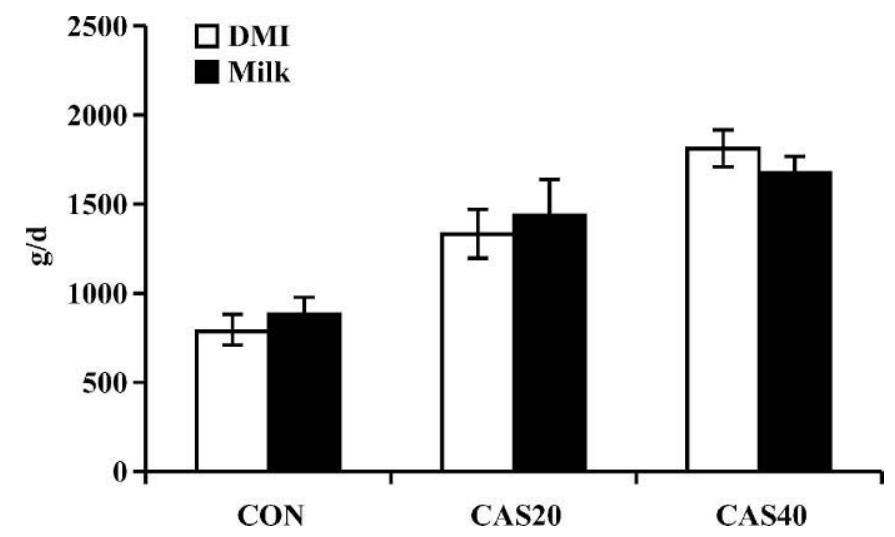

Figure 2. Dry matter intake and milk production (g/d) of dairy goats $(\mathrm{n}=2)$ abomasally infused daily with $1000 \mathrm{~g}$ water $(\mathrm{CON})$, casein hydrolysate solution equaling $20 \%$ of metabolizable protein intake (CAS20), or casein hydrolysate solution equaling $40 \%$ of metabolizable protein intake (CAS40). Results are least square means $\pm \mathrm{SE}$. 


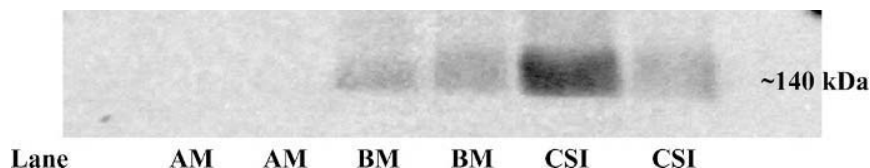

Figure 3. Western blot analysis of aminopeptidase N (APN) with monoclonal antibody raised against CD13 from human U937 cells. Lane identification: $\mathrm{AM}=$ apical plasma membrane vesicles, $\mathrm{BM}=$ basal plasma membrane vesicles, and CSI = positive control from brush border membrane vesicles from chicken small intestine, fasted and fed, respectively.

CAS20 and CAS40, respectively. Milk yield was increased by $68 \%$ when goats received CAS20 and by $129 \%$ when goats received CAS40, compared with the control treatment. The essential FAA and PBAA concentrations in arterial plasma gave apparent evidence that the casein hydrolysate was absorbed from the small intestine and some AA were transported in the form of peptides. With the exception of Met PBAA, concentrations in arterial plasma were increased by $49 \%$ $(P<0.001$ to 0.0001$)$ and $150 \%$ with the infusion of CAS20 and CAS40, respectively. Overall, total essential AA concentrations including PBAA were apparently increased in arterial plasma by 70 and $190 \%$ when CAS20 and CAS40 were infused, respectively.

\section{Main Study-Goat Performance}

All goats completed the experiment and remained healthy. Goats fully recovered after each biopsy within 5 to $7 \mathrm{~d}$, and no signs of milk reduction were noticed after the surgical procedure. Goats on both dietary treatments produced similar amounts of milk (1000 \pm $84 \mathrm{~g} / \mathrm{d}$ ) and consumed $1311 \pm 113 \mathrm{~g}$ of DM daily. Milk protein concentration was similar for both treatments and averaged $38.1 \pm 0.14 \mathrm{~g} / \mathrm{L}$ ).

\section{APN Protein Abundance in Mammary Gland on the Basal Side of the Parenchymal Cells}

To detect APN protein abundance, Western blot analysis was performed on membranes prepared from mammary tissue (goat and cow), milk, and PMV from intestinal brush border of chicken and rat (Figures 3 and 4). Monoclonal and polyclonal anti-CD 13 antibodies were used to detect the APN protein in the different tissues and to ensure the specificity of the polyclonal antibody to APN.

In all tissues examined, both antibodies detected a band at approximately $140 \mathrm{kDa}$. The APN protein was not detected in PMV prepared from milk. The PMV preparations from milk are believed to be from the apical side of the epithelial cells in the productive tissue of the mammary gland (Shennan, 1992).
$\mathbf{A}$

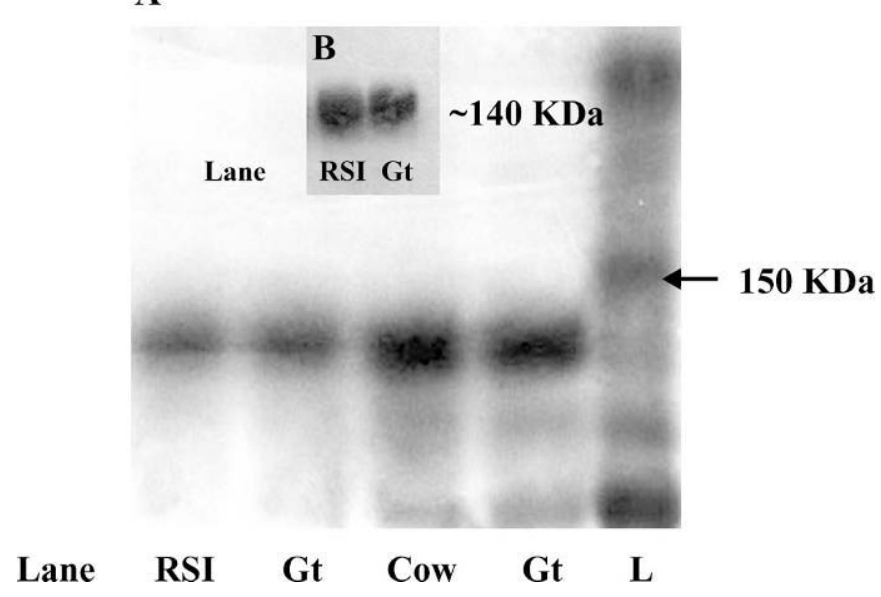

Figure 4. A. Western blot analysis of aminopeptidase N (APN), Lane identification: $\mathrm{RSI}=$ rat small intestine, $\mathrm{Gt}=$ plasma membrane vesicles of lactating mammary goat, Cow $=$ plasma membrane vesicles of lactating mammary cow, and $\mathrm{L}=$ protein ladder. This blot was performed with goat polyclonal antibody raised against human APN. $\mathrm{B}$. The inset blot was conducted with monoclonal antibody raised against human U937 cells. Lane identification: RSI = positive control (small intestine brush border membrane vesicles of chicks), and lane $\mathrm{Gt}=$ plasma membrane vesicles from lactating goat.

In accordance with these results (Figure 3 and 4), the polyclonal anti-CD 13 was used for Western blot analysis in tissues taken by biopsy from goats subjected to the different treatments.

\section{Effect of Casein Hydrolysate Infusion on Arterial Plasma FAA and PBAA, mRNA, and Protein Abundance of APN in Caprine Mammary Gland}

Presented in Figure 5 are the FAA and PBAA concentrations in arterial plasma of goats $(n=2)$ receiving similar MPI in 2 different forms (casein infusion vs. MP from diet). Results confirm the success of the infusion treatments. Concentrations of arterial FAA in both treatments were not significantly different for AA measured. However, PBAA concentrations were greater $(P$ $<0.01$ to 0.001 ) for most AA in the casein-infused goats compared with control goats. It was expected in this experiment, that when infusate replaced rather than added MP, that the overall MP would be similar for both treatments (control and CAS30); however, the plasma profile of AA shifted toward higher $(P<0.05)$ PBAA in the circulation (Figure 5).

The mammary gland aminopeptidase cDNA fragment was analyzed, and the nucleic acid sequence was published in GenBank (AJ304432). The homology between goat and other aminopeptidase sequences was calculated and averaged 76 to $84 \%$ for chicken and human intestine, respectively. 

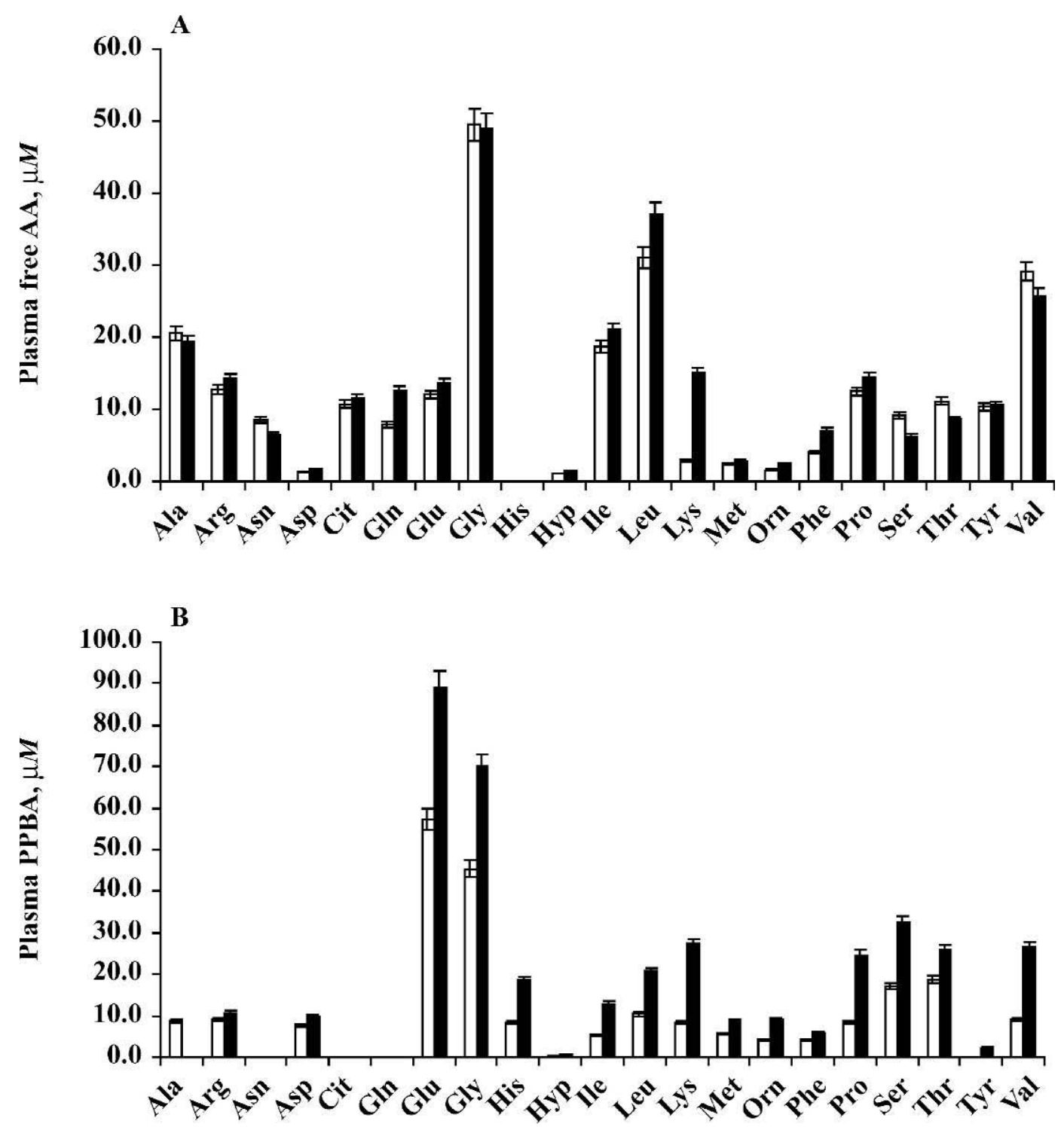

Figure 5. Concentration of free AA (A) and peptide-bound AA (B) in arterial plasma of dairy goats ( $\mathrm{n}=2$; main study) abomasally infused

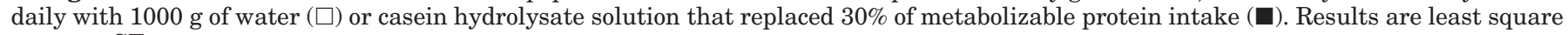
means $\pm \mathrm{SE}$.

Aminopeptidase $\mathrm{N}$ mRNA abundance detected by Northern blot analysis (Figure 6) was increased by $51 \%$ $(P<0.05)$ in goats undergoing casein hydrolysate infusion compared with control animals. The APN protein appearance on PMV prepared from mammary tissues of goats changed in a manner similar to mRNA expression. Protein expression of APN was increased by $58 \%$ $(P<0.02)$ in the casein hydrolysate-treated goats compared with controls (Figure 7).

\section{DISCUSSION}

The primary aim of the current study was to investigate whether PBAA concentration in the circulation affects expression of APN in the mammary gland. We proposed that APN could be one of the mechanisms involved in acquiring substrates to be used for milk protein synthesis and secretion. Hence, its expression should be sensitive to any metabolic challenge at the substrate level. Based on published results (Shennan et al., 1999, 1998), APN might be one of the peptidases involved in providing AA for protein synthesis in the gland. Moreover, the mechanisms of how the activity of this enzyme might be affected by circulating peptides is one step toward understanding the metabolic pathways by which AA and PBAA are used by the lactating mammary gland of ruminants. Hence, casein hydroly- 


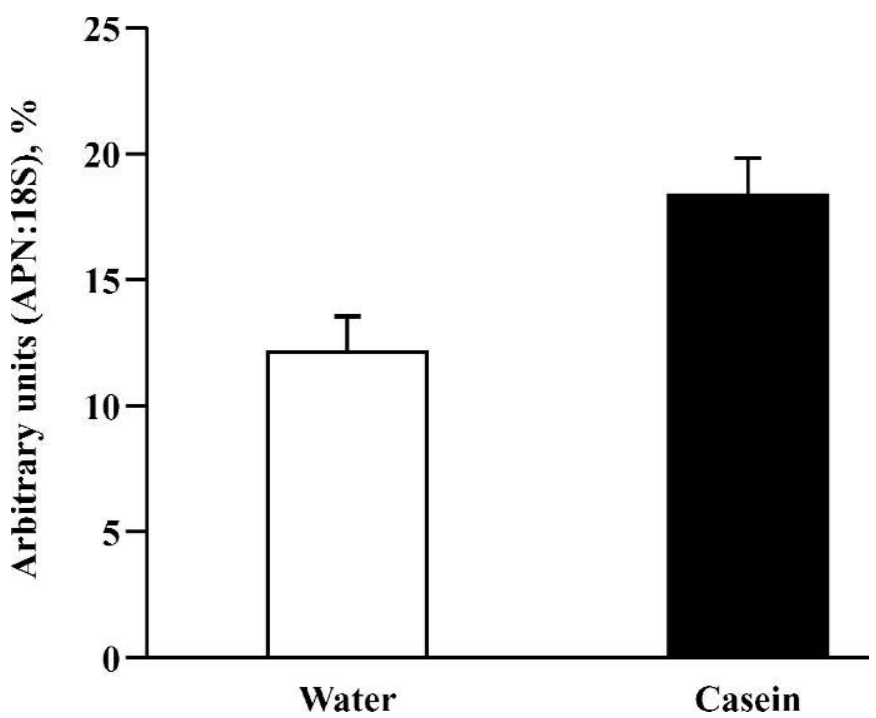

Figure 6. Northern blot analysis of aminopeptidase N (APN) expression in mammary gland tissue taken from goats $(n=4)$ infused with $1000 \mathrm{~g} / \mathrm{d}$ of water $(\square)$ or with casein hydrolysate solution that replaced $30 \%$ of metabolizable protein intake in $1000 \mathrm{~g} / \mathrm{d}$ of water (CAS30; $\mathbf{0})$. Expression of APN in the CAS30 treatment was increased by $51 \%(P<0.05 ; \mathrm{SEM}=4.72 ; \mathrm{n}=4)$ compared with the control treatment. Each blot was conducted in triplicates. Results are least square means $\pm \mathrm{SE}$.

sate infusion into the stomach was used to imitate the effect of dietary challenges that might cause an increase in peptide flow and absorption and portal appearance of PBAA (Delgado-Elorduy et al., 2002).

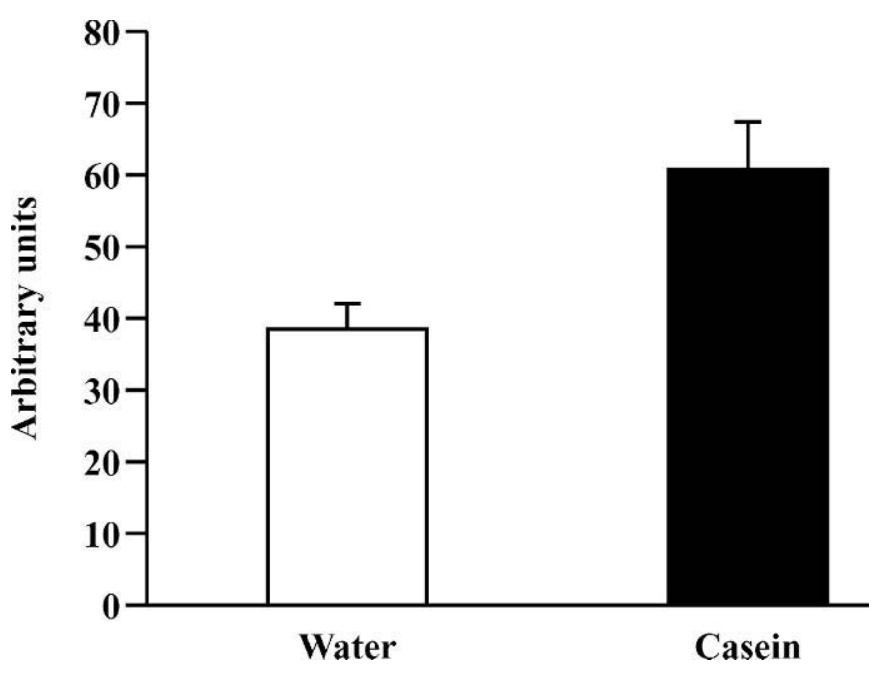

Figure 7. Western blot analysis of APN expression in mammary gland tissue taken from goats $(\mathrm{n}=4)$ infused with $1000 \mathrm{~g} / \mathrm{d}$ of water $(\square)$ or with casein hydrolysate solution that replaced $30 \%$ of metabolizable protein intake in $1000 \mathrm{~g} / \mathrm{d}$ of water ( $)$. Abundance of APN in casein hydrolysate-infused goats was increased by $58 \%(P<0.02$; $\mathrm{SEM}=16.0 ; \mathrm{n}=4$ ) compared with the control treatment. Each blot was performed in triplicate. Results are least square means $\pm \mathrm{SE}$.
Indeed, the results of the preliminary and the main experiments confirmed that at least a portion of MP was absorbed from the small intestine in the form of peptides and caused an increased PBAA concentration in arterial blood. This is in agreement with previously published data from dairy cows that used the same approach (Choung and Chamberlain, 1995). Variable contributions of PBAA to the total concentration of AA have been reported. For example, Seal and Parker (1996) reported 26 to $28 \%$, Koeln et al. (1993), Remond et al. (2000), and Tagari et al. (2004) reported 64, 38, and $21 \%$, respectively, of PBAA concentrations as a percentage of total AA concentration. In the preliminary study, the contribution of essential PBAA in arterial plasma averaged $29 \%$ of total AA concentrations and was similar for all treatments. In the main study, PBAA contribution ranged from $10 \%$ in the control treatment to $40 \%$ in the casein infusion.

Tissue use and absorption of intact peptides is well recognized across different nutritional states (Adibi 1987; Hubl et al., 1989). The concept of PBAA contributing to mammary gland metabolism and protein synthesis and secretion has been observed in different studies. Published data from in vivo studies indicated that the caprine lactating mammary gland could use many essential AA in the form of PBAA for milk protein synthesis (Backwell et al., 1996; Bequette et al., 1999). The bovine mammary gland also extracts essential AA from the circulation in the form of peptides (Tagari et al., 2004). For example, Met (48 to $71 \%$ ) and Lys (37 to $60 \%$ ) are extracted by the mammary gland as PBAA depending on the dietary treatment. It was suggested that corn processing might cause greater microbial protein synthesis in the rumen and thus increase MP flow to the small intestine, which affects the contribution of PBAA to the AA flux of portal-drained viscera as well as to the mammary gland (Tagari et al., 2004).

In vivo studies demonstrated, by kinetic methods with labeled AA using the precursor-product tracer technique, that the mammary gland is able to use peptides as a source of AA for protein synthesis under different dietary conditions such as a shortage of certain AA or different physiological states (Bequette et al., 2000; Mabjeesh et al., 2000). The mechanism by which PBAA uptake occurs is not yet clear. For example, mRNA for peptide transport systems was not detected in lactating mammary gland from cows (Chen et al., 1999). Another route for uptake was suggested, however, such as peptidase proteins that are embedded in the basolateral membrane of the parenchymal cells in the gland. Shennan et al. $(1999,1998)$ suggested that transport of intact dipeptides by perfused rat mammary gland was very low even under conditions designed to maximize uptake. However, it was shown that the 
mammary gland has a large capacity to hydrolyze dipeptides on the basolateral side; the contribution of FAA influx by the lactating mammary gland is quantitatively more significant than uptake of intact peptides (Shennan et al., 1998).

In the current study, we replaced $30 \%$ of the MPI by a casein hydrolysate infusion (CAS30) to ensure isonitrogenous MP supply and to satisfy lactation requirements. It was hypothesized that increasing circulating peptides with a constant MP supply would cause a direct effect on the activity and expression of the mechanism responsible (e.g., APN) for PBAA uptake into the mammary gland, with minor effects on the level of milk protein secretion.

It was also important to show that APN is exclusively expressed on the basal side of the gland (Figure 3 and 4) and not at the apical membrane. This is because APN is located on intralobular and interlobular fibroblasts and on the apical surface of epithelial cells, at least in human nonlactating breast tissue (Atherton et al., 1992, 1994). Nevertheless, in the current study, the basolateral location of APN supports the finding of Shennan et al. $(1998,1999)$ that peptides are hydrolyzed extracellularly on the blood-facing membrane, and then FAA are taken up by the gland via highaffinity transporters. Recently, it was shown that the enzyme $\gamma$-glutamyl transpeptidase is expressed in ovine mammary gland tissue and is located on the basolateral side of the productive cells (Johnston et al., 2004). Moreover, it was affected by physiological state, such as pregnancy or lactation. It is noteworthy that plasma membranes prepared in the current study may include portions of other supportive tissues in the gland such as connective tissue.

It appears that APN is influenced by peptide concentrations in arterial blood. Northern and Western blot analysis of mRNA and PMV protein extracted from mammary tissues showed that increasing the relative portion of PBAA concentration in the circulation of lactating goats caused a 51 and $58 \%$ increase in the gene expression and protein, respectively. This finding may be explained as a direct effect of the increase in arterial peptide concentration, albeit without changing the overall supply of AA that satisfies milk requirements. The parallel increase in gene and protein expression observed in goats subjected to casein hydrolysate infusion supports the concept that mRNA was translated to protein to support the demand of the tissue for AA supply for protein synthesis. This might indicate that the mammary tissue senses the lack of FAA, and metabolite signals, which might be extracellular (e.g., PBAA and FAA) or intracellular to regulate the APN expression and activity. Similarly, intestinal peptidase activity is regulated by a mechanism that involves precur- sors and products of peptide hydrolysis in humans (Sanderink et al., 1988; Kushak and Winter, 1999) and rats (Zarrabian et al., 1999). These factors may regulate APN via mRNA abundance as well as protein expression. Indeed, in vivo experiments showed in indirect measurements that mammary tissue has the ability to overcome a limitation in availability of a single AA (such as His or Lys) by increasing blood flow, uptake, and extraction of AA from blood in both forms of FAA and PBAA (Bequette et al., 2000; Mabjeesh et al., 2000). Therefore, APN may play a role in milk protein synthesis and secretion. This would be similar to the role of $\gamma$-GT, which plays an important role in milk protein production in the ovine lactating mammary tissue (Johnston et al., 2004). Inhibition of $\gamma$-GT by incubating the tissues with specific inhibitor (acivicin) decreased milk protein secretion by $75 \%$.

In conclusion, APN and other peptidases such as $\gamma$ GT are candidates for active involvement in the mammary gland to support protein synthesis and milk production. Expression and activity of these enzymes might be orchestrated in accordance to the nutritional and physiological conditions. From the current study, it appears that APN expression may be partly controlled by the metabolic requirements of the gland and postabsorptive forms of AA in the circulation.

\section{REFERENCES}

Adibi, S. A. 1987. Experimental basis for use of peptides as substrates for parenteral nutrition: A review. Metabolism 36:1001-1011.

AFRC. 1992. Nutritive Requirements of Ruminant Animals: Protein. Technical Committee on Responses to Nutrients, Agric. Food Res. Council. Rep. No. 9. Nutr. Abstr. Rev. 62:787-835.

AFRC. 1993. Energy and Protein Requirements of Ruminants. An Advisory Manual. Technical Committee on Responses to Nutrients, Agric. Food Res. Council. CAB Int., Wallingford, UK.

Arieli, A., I. Bruckental, and E. Smoler. 1989. Prediction of duodenal nitrogen supply from degradation or organic and nitrogenous matter in situ. J. Dairy Sci. 72:2532-2539.

Atherton, A. J., P. Monaghan, M. J. Warburton, and B. A. Gusterson. 1992. Immunocytochemical localization of the ectoenzyme aminopeptidase $\mathrm{N}$ in the human breast. J. Histochem. Cytochem. 40:705-710.

Atherton, A. J., M. J. O'Hare, L. Buluwela, J. Titley, P. Monaghah, H. F. Paterson, M. J. Warburton, and B. A. Gusterson. 1994. Ectoenzyme regulation by phenotypically distinct fibroblast subpopulations isolated from the human mammary gland. J. Cell Sci. 107:2931-2939.

Backwell, F. R., B. J. Bequette, D. Wilson, J. A. Metcalf, M. F. Franklin, D. E. Beever, G. E. Lobley, and J. C. MacRae. 1996. Evidence for the utilization of peptides for milk protein synthesis in the lactating dairy goat in vivo. Am. J. Physiol. 271:R955-R960.

Backwell, F. R. C., M. Hipolito-Reis, D. Wilson, L. A. Bruce, and V. Buchan. 1997. Quantification of circulating peptides and assessment of peptide uptake across the gastrointestinal tract of sheep. J. Anim. Sci. 75:3315-3322.

Bequette, B. J., F. R. Backwell, and L. A. Crompton. 1998. Current concepts of amino acid and protein metabolism in the mammary gland of the lactating ruminant. J. Dairy Sci. 81:2540-2559.

Bequette, B. J., F. R. Backwell, C. E. Kyle, A. G. Calder, V. Buchan, L. A. Crompton, J. France, and J. C. MacRae. 1999. Vascular 
sources of phenylalanine, tyrosine, lysine, and methionine for casein synthesis in lactating goats. J. Dairy Sci. 82:362-377.

Bequette, B. J., M. D. Hanigan, A. G. Calder, C. K. Reynolds, G. E. Lobley, and J. C. MacRae. 2000. Amino acid exchange by the mammary gland of lactating goats when histidine limits milk production. J. Dairy Sci. 83:765-775.

Bidlingmeyer, B. A., S. A. Cohen, and T. L. Tarvin. 1984. Rapid analysis of amino acids using pre-column derivatization. J. Chromatogr. 336:93-104.

Chen, H., E. A. Wong, and K. E. Webb, Jr. 1999. Tissue distribution of a peptide transporter mRNA in sheep, dairy cows, pigs, and chickens. J. Anim. Sci. 77:1277-1283.

Choung, J. J., and D. G. Chamberlain. 1995. Effects of abomasal infusions of sodium caseinate and of casein hydrolysates varying in the relative proportions of peptides and free amino acids on milk production in dairy cows. J. Dairy Res. 62:423-429.

Danilson, D. A., K. E. Webb, Jr., and J. H. Herbein. 1987. Transport and hindlimb exchange of peptide and serum protein amino acids in calves fed soy- or urea-based purified diets. J. Anim. Sci. 64:1852-1857.

Delgado-Elorduy, A., C. B. Theurer, J. T. Huber, A. Alio, O. Lozano, M. Sadik, P. Cuneo, H. D. De Young, I. J. Simas, J. E. Santos, L. Nussio, C. Nussio, K. E. Webb, Jr., and H. Tagari. 2002. Splanchnic and mammary nitrogen metabolism by dairy cows fed dry-rolled or steam-flaked sorghum grain. J. Dairy Sci. 85:148159.

Devereux, J., P. Haeberli, and O. Smithies. 1984. A comprehensive set of sequence analysis programs for the VAX. Nucleic Acids Res. 12:387-395.

Hubl, W., W. Druml, K. Langer, and H. Lochs. 1989. Influence of molecular structure and plasma hydrolysis on the metabolism of glutamine-containing dipeptides in humans. Metabolism 38(Suppl. 1):59-62.

Johnston, S. L., K. E. Kitson, J. W. Tweedie, S. R. Davis, and J. Lee. 2004. Gamma-glutamyl transpeptidase inhibition suppresses milk protein synthesis in isolated ovine mammary cells. J. Dairy Sci. 87:321-329.

Koeln, L. L., T. G. Schlagheck, and K. E. Webb, Jr. 1993. Amino acid flux across the gastrointestinal tract and liver of calves. J. Dairy Sci. 76:2275-2285.

Kushak, R. I., and H. S. Winter. 1999. Regulation of intestinal peptidases by nutrients in human fetuses and children. Comp. Biochem. Physiol. A Mol. Integr. Physiol. 124:191-198.

Laemmli, U. K. 1970. Cleavage of structural proteins during the assembly of the head of bacteriophage T4. Nature 227:680-685.

Mabjeesh, S. J., M. Cohen, O. Gal-Garber, A. Shamay, and Z. Uni. 2001. Amino peptidase gene expression in caprine mammary gland: A possible role in peptide-bound amino acid uptake. J. Dairy Sci. 84(Suppl. 1):313.

Mabjeesh, S. J., D. Guy, and D. Sklan. 2003. Na+/glucose co-transporter abundance and activity in the small intestine of lambs: Enhancement by abomasal infusion of casein. Br. J. Nutr. 89:573-580.

Mabjeesh, S. J., C. E. Kyle, J. C. MacRae, and B. J. Bequette. 2000. Lysine metabolism by the mammary gland of lactating goats at two stages of lactation. J. Dairy Sci. 83:996-1003.

Matthews, D. M. 1991. Protein Absorption. Development and Present State of the Subject. Wiley-Liss, Inc., New York, NY.

Matthews, J. C., E. A. Wong, P. K. Bender, J. R. Bloomquist, and K. E. Webb, Jr. 1996a. Demonstration and characterization of dipeptide transport system activity in sheep omasal epithelium by expression of mRNA in Xenopus laevis oocytes. J. Anim. Sci. 74:1720-1727.
Matthews, J. C., E. A. Wong, P. K. Bender, and K. E. Webb, Jr. 1996b. Demonstration and characterization of a transport system capable of lysine and leucine absorption that is encoded for in porcine jejunal epithelium by expression of mRNA in Xenopus laevis oocytes. J. Anim. Sci. 74:127-137.

McCormick, M. E., and K. E. Webb, Jr. 1982. Plasma free, erythrocyte free and plasma peptide amino acid exchange to calves in steady state and fasting metabolism. J. Nutr. 112:276-282.

Pan, Y., P. K. Bender, R. M. Akers, and K. E. Webb, Jr. 1996. Methionine-containing peptides can be used as methionine sources for protein accretion in cultured $\mathrm{C} 2 \mathrm{C} 12$ and MAC-T cells. J. Nutr. 126:232-241.

Pan, Y., E. A. Wong, J. R. Bloomquist, and K. E. Webb, Jr. 2001. Expression of a cloned ovine gastrointestinal peptide transporter (oPepT1) in Xenopus oocytes induces uptake of oligopeptides in vitro. J. Nutr. 131:1264-1270.

Pan, Y. X., E. A. Wong, J. R. Bloomquist, and K. E. Webb, Jr. 1997. Poly(A)+ RNA from sheep omasal epithelium induces expression of a peptide transport protein(s) in Xenopus laevis oocytes. J. Anim. Sci. 75:3323-3330.

Remond, D., L. Bernard, and C. Poncet. 2000. Free and peptide amino acid net flux across the rumen and the mesenteric- and portaldrained viscera of sheep. J. Anim. Sci. 78:1960-1972.

Sanderink, G. J., Y. Artur, and G. Siest. 1988. Human aminopeptidases: A review of the literature. J. Clin. Chem. Clin. Biochem. 26:795-807.

SAS Institute. SAS User's Guide. Statistics, Version 5th ed. 1985. SAS Inst. Inc., Cary, NC.

Seal, C. J., and D. S. Parker. 1996. Effect of intraruminal propionic acid infusion on metabolism of mesenteric- and portal-drained viscera in growing steers fed a forage diet. II. Ammonia, urea, amino acids, and peptides. J. Anim. Sci. 74:245-256.

Shennan, D. B. 1992. $\mathrm{K}^{+}$and $\mathrm{Cl}^{-}$transport by mammary secretory cell apical membrane vesicles isolated from milk. J. Dairy Res. 59:339-348.

Shennan, D. B., F. R. Backwell, and D. T. Calvert. 1999. Metabolism of aminoacyl-p-nitroanilides by rat mammary tissue. Biochim. Biophys. Acta 1427:227-235.

Shennan, D. B., D. T. Calvert, F. R. Backwell, and C. A. Boyd. 1998. Peptide aminonitrogen transport by the lactating rat mammary gland. Biochim. Biophys. Acta 1373:252-260.

Tagari, H., K. Webb, Jr., B. Theurer, T. Huber, D. DeYoung, P. Cuneo, J. E. Santos, J. Simas, M. Sadik, A. Alio, O. Lozano, A. DelgadoElorduy, L. Nussio, C. Nussio, and F. Santos. 2004. Portal drained visceral flux, hepatic metabolism, and mammary uptake of free and peptide-bound amino acids and milk amino acid output in dairy cows fed diets containing corn grain steam flaked at 360 or steam rolled at $490 \mathrm{~g} / \mathrm{L}$. J. Dairy Sci. 87:413-430.

Taylor, R. E., and T. G. Field. 1998. Scientific Farm Animal Production: An Introduction to Animal Science. 6th ed. Prentice Hall, Saddle River, NJ.

Vayro, S., R. Kemp, R. B. Beechey, and S. Shirazi-Beechey. 1991. Preparation and characterization of basolateral plasma-membrane vesicles from sheep parotid glands. Mechanisms of phosphate and D-glucose transport. Biochem. J. 279:843-848.

Wang, S., K. E. Webb, Jr., and M. R. Akers. 1996. Peptide-bound methionine can be a source of methionine for the synthesis of secreted proteins by mammary tissue explants from lactating mice. J. Nutr. 126:1662-1672.

Zarrabian, S., J. P. Buts, G. Fromont, T. U. Tran, J. Macry, F. Mendy, L. Roger, and J. P. Cezard. 1999. Effects of alimentary intact proteins and their oligopeptide hydrolysate on growth, nitrogen retention, and small bowel adaptation in inflammatory turpentine rat. Nutrition 15:474-480. 